\title{
Bilingualism in Medieval Italian Preaching: The Case of Angelo da Porta Sole (d. 1334)
}

\section{Carlo Delcorno*}

This article examines the language of an important collection of sermons by Angelo da Porta Sole, predicator generalis of the Dominican Order and Bishop of Grosseto, who preached in Tuscany in the early fourteenth century. It is a very early case of the macaronic sermon, in the wider sense of the term (not to be confused with a very particular kind of late fifteenth-century Italian preaching). Adopting the scheme proposed by Siegfried Wenzel for English macaronic sermons, this article examines three ways in which Latin and the Umbrian vernacular are combined in Angelo da Porta Sole's sermons, namely: the insertion of a vernacular word in a Latin sentence; the presence of vernacular glosses of Latin words and etymological doublets; extended and frequent switching from Latin to the vernacular and vice versa. The last typology, which constitutes the fully macaronic mode, is frequently employed in dramatic or narrative contexts, particularly in sermons on Good Friday and at Easter.

Keywords: medieval preaching; Dominicans; bilingual sermons; Latin sermons; Umbrian vernacular

In the documents concerning the preaching practised in Italy in the thirteenth and fourteenth centuries an ever-more frequent mixing of the "latinus grossus « of spoken usage with the vernacular lexis can be observed. Broadly speaking, we can speak of "macaronic «, ${ }^{1}$ with the caveat of distinguishing between such bilingualism and the artificial language of the "macaronic sermons" of the fifteenth century, due to the inventiveness of some famous preachers of the Mendicant Orders. ${ }^{2}$ There is no agreement among scholars as to the actual use of this hybrid language, whether it was a simple written exercise or a form of effective communication. At present, a cautious attitude prevails, and the belief that the study of

* Correspondence details: Carlo Delcorno, University of Bologna, Dipartimento di Filologia classica e Italianistica, Via Zamboni, 32, 40126 Bologna, Italy; email: carlo.delcorno@unibo.it.

1 Cf. Wenzel, Macaronic Sermons, 5.

2 For this fundamental distinction, refer to Delcorno, Tra latino e volgare, in particular 34-35. On the »macaronic" sermons, strictly speaking, of the fifteenth century, cf. Lazzerini, "Per latinos grossos...«; id., Testo trasgressivo, ch. 2: Da quell'arzillo pulpito: "Sermo humilis« and macaronic sermons in the autographed Lenten of Valeriano da Soncino O.F.P. 
the individual cases must be intensified, distinguishing between the times and the cultural spheres. ${ }^{3}$ Linguistic hybridism is greatly reduced in the large school sermon books, the most diffuse ones, such as the collections of Iacopo da Varazze, ${ }^{4}$ while, by contrast, it surfaces more decidedly in the thirteenth-century collections used by individual preachers or those with a limited circulation. ${ }^{5}$ In the fourteenth century, when, particularly in Tuscany, vernacular predication is reported directly by the listeners themselves, by then capable of handling the new language and aware of its dignity and literary beauty, ${ }^{6}$ we also notice a profound change in the Latin sermon books, in which the presence of vernacular insertions is broader and more frequent. A particularly significant case is the great collection of sermons of Angelo da Porta Sole, of which at present a single copy is known. This source invites us to rectify the idea, maintained by Lucia Lazzerini, that the macaronic sermon is a completely new language of preaching invented at the end of the fifteenth century and the first decade of the sixteenth century in northern Italy, particularly in Padua, at the intersection between the university and the pulpit, and thanks also to a significant interplay with the truly macaronic poetry. On the contrary, the Latin sermons of Angelo da Porta Sole (and those of some others preachers that need to be adequately studied) prove that many forms of linguistic hybridism were already in use in the first decades of the Trecento, anticipating communicative techniques that would later be developed into fully fledged forms by famous popular preachers such as Cherubino da Spoleto, Bernardino da Feltre and Valeriano da Soncino.

\section{Angelo "perusinus" or da Porta Sole}

Born in the neighbourhood of Porta Sole in Perugia in around 1280, win die angelorum«, declares the Chronica of the convent of San Domenico, ${ }^{7}$ he was welcomed between the age of thirteen and fifteen into the Order of the Preachers, studied theology in Siena (1305), and then pursued the career of teacher in the Tuscan and Umbrian convents: lector in philosophy in Prato (1310-1311), and in theology in Perugia (1311-1312). Prior in the convents of Città di Castello, Perugia and Pisa, he was distinguished for his qualities as a preacher: the Provincial Chapter of Anagni (1317) appointed him praedicator generalis, a privilege confirmed

3 Cf. Bériou, Latin et langues vernaculaires, and then in id., Religion et communication, 84: "Il nous faut reconnaitre la fragilité de nos savoirs et l'impossibilité de trancher sommairement entre les deux hypothèses. En l'état actuel de nos connaissances il convient surtout de ne pas adopter d'attitude dogmatique, et de rester sensible à la variété des situations, voire à des transformations induites par le temps«. Lazzerini believed »the vexata quaestio of the relationship between writing and orality in preaching to be probably insoluble« (Testo trasgressivo, 88).

4 Iacopo da Varazze, Sermones quadragesimales, ed. Maggioni.

5 For some examples, gleaned from the sermon books of the thirteenth century (Ambrogio Sansedoni, Bartolomeo da Vicenza, Federico Visconti), see Delcorno, Tra latino e volgare, 27-35. See also Delcorno, Language of preachers.

6 The most important document is the corpus of the preaching of Giordano da Pisa (or da Rivalta), collected in Florence and in Pisa between 1303 and 1309. Cf. Delcorno, Giordano da Pisa.

7 Chronica Ordinis Fratrum Predicatorum Perusini conventus. Cf. Cronaca di S. Domenico di Perugia, ed. Maiarelli, 78. Besides this fundamental document, see Kaeppeli, Scriptores, 77-78; Dessì, Porta Sole; id., Spectres du Bon Gouvernement (Angelo da Porta Sole, un prédicateur dans les affaires des Communes). 
in $1320 .{ }^{8}$ The Chronica insists on the success of his preaching in Pisa, Rome, Florence and, lastly, in Avignon (pre-1330), where he took the floor before the great prelates in the pontifical curia and was granted particular honours. ${ }^{9}$ In terms of his culture, having attended the Avignon curia was of great importance, although this has yet to be properly evaluated. ${ }^{10}$ John XXII, who had already nominated him apostolic penitentiary in Rome and then bishop of Sulci in Sardinia (1325), confirmed his esteem for Angelo's culture and sanctity by sending him to the episcopal seat of Grosseto (12th February 1330), whence, however, Friar Angelo was unable to go owing to the city's opposition. He withdrew to Ischia (Istia di Ombrone), a castle just a few kilometres from Grosseto, where he died on 11th May 1334.

\section{Sermons of Angelo da Porta Sole:}

Firenze, Biblioteca Nazionale Centrale, Conv. Sopp. B.8.1637

The sermons of Angelo da Porta Sole must have circulated in the Roman Province, as attested to by an inventory of the library of San Domenico di Perugia (1458). ${ }^{11}$ At present we know of only one codex of the Biblioteca Nazionale di Firenze, coming from the convent of the Servi di Maria, the SS. Annunziata, ${ }^{12}$ the codex Conv. Sopp. B.8.1637. ${ }^{13}$

Written on parchment, mm. $190 \times 140$, sec. XIV, restored with binding in wooden plates, leather back, paper guards ( 2 at the beginning and 2 at the end), fols. I (paper), 327, II'. Modern foliation in pencil (performed during the restoration). At fol. 5 the sermon book begins, as does the ancient foliation in Roman numerals, highly irregular (I-CCCXXVIII), marked in the upper corner of the recto and often also repeated in the verso. Blank fols. 253r-v, 281v, 311r-v, 327v. The text is written by different scribes (A fol. 5r, B fol. 254r) on a full page, ruled in plummet, 30 lines per side.

8 Cf. Acta Capitulorum Provincialium Provinciae Romanae (1243-1344), ed. Kaeppeli and Dondaine, 221 (Capitolo di Pisa 1320): "Assignamus pro predicatore generali totius Provincie fr. Angelum Perusinum secundum ordinationem prioris provincialis, cui volumus quod cedant ceteri predicatores cum pervenerit ad conventum cum plena libertate lectoris actu legentis«. (We designate as general preacher for all the Province Friar Angelo Perugino in accordance with the order of the provincial prior, and order that when he shall arrive in a convent all the other preachers shall cede to him the place with total licence of the teacher in charge).

9 Cronaca di S. Domenico 126, 80: "Non solum in sua romana Provincia semen sue predicationis quod est verbum Dei multiplicavit in centuplum, sed et ubicumque fuit. Nam in Avinione in curia domini pape, eo predicante multi magni domini et reverendi prelati conveniebant«. (Not only in the Roman Province, to which he belonged, multiplied by one hundred the seed of his preaching, that is the Word of God, but also in every place where he went. Indeed, many great lords and ecclesiastic reverends gathered to listen to him when he preached at Avignon in the curia of your excellency, the Pope).

10 The attention to the classics and, above all, to Titus Livius (Livy) owes much to the atmosphere in Avignon and to John XXII himself, who had charged the Dominican Nicola Treveth with writing a comment to the stories of Livy and entertained relations of friendship with a scholar of the Livian text, Landolfo Colonna. Cf. Smalley, English Friars, 60; Billanovich, Tradizione del testo, 158. On this aspect of the culture of Friar Angelo, cf. Delcorno, "Antico« e »moderno«, 114-115.

11 Kaeppeli, Inventari, 136-138. They are the numbers 147, 162, 168 of the inventory dated 1458.

12 Cf. Soulier, Inventarium codicum, 174.

13 See the detailed description in Pellegrini, Manoscritti. 
On the initial flyleaf the old shelf mark is indicated: "Annunziata 1637«. In the first leaves (not numbered in the ancient cartulation) the series of sermons is listed according to the liturgical order. The table is started by a first hand that writes only column A of fol. 1; a second hand repeats the table on column B with a clearer reference to the folios of the codex and continues with the list of the sermons De Tempore (1rb-1va-b) and De sanctis (2ra). The codex should have been longer as the list of 36 sermons of the temporal cycle (2rb-va) follows "secundum fratrem Ambrosium senensem" (composed by Friar Ambrogio di Siena). Different writing hands in textual Gothic. Modest and irregular decoration. Blue filigreed in red is used for the initial $(\mathrm{H})$ of the first sermon (Hora est iam de somno surgere) (It is now time to awake from sleep); the initials of the thematic verses are often in red. The indications of the liturgical dates are added by an identical tiny letter in the margins.

It contains 124 sermons: s. 1-84 De Tempore (fols. $5 \mathrm{r}-252 \mathrm{v})^{14}$, s. 85-124 De sanctis, de b. Maria, pro Defunctis and in Communi, and lastly three more sermons for Lent and a sermon for Advent (fols. 254r-327r). Incipit: Incipiunt sermones de tempore secundum fratrem Angelum perusinum Ordinis Predicatorum (in darker ink on erasure "Angelum perusinum Ordinis Predicatorum«). Expl. Quia non erit postea generatio nec corruptio hominum nec aliarum creaturarum. Rogemus ergo et cetera. (Incipit The sermons De tempore begin composed by Angelo Perugino of the Order of the Preachers ... Explicit As subsequently there will be neither generation nor corruption of men nor of other creatures).

The book of sermons is an instrument in the service of the preachers, not of the common reader. This is proven by the frequent references to legends and exempla that need not be reported in detail. For example, it is noted: "Dic hic exemplum beati Machari qui uidit demonium euntem ad monachos cum uestimento lineo pleno ampullis" (At this point you must tell the story of Saint Macarius who saw the devil go to the monks wearing a linen garment on which were hanging many jars) (95r, dom. IIa in Quadragesima), "Dic hic miracula de legenda sua " (Here you must tell of the miracles narrated by his legend) (275r De Sancto Petro Martire) ${ }^{15}$ Frequent annotations at the start of the sermon are: $» D i c$ hic ystoriam Euangelii« (Tells the story of the Gospel) (42v, 82r, 110r, 166r, 209v, 218v, 240r); "Dic ystoriam Euangelii« (You will tell the Gospel) (122r, 182r, 227v, 232v, 322v); "Dicas ystoriam Euangelii« (Tells the Gospel) (95v); »Dic istoriam" (204v). Arguments are repeated with small changes in different sermons. Hence, the list of the four signs of friendship indicated in the sermon Assumpsit Ihesus.XII. discipulos suos (Jesus took with him twelve of his disciples) (75r) is reasserted in the sermon Assumpsit Ihesus Petrum Iacobum et Iohannem (Jesus took with him Peter James and John) (99r); the spices produced in the warm countries, an allegory for the flourishing virtues of charity, are recalled in the sermon for Saint Stephen (26or) and in the one for Saint Domenic (278v); the four episodes in which Christ was "in medio" (in the middle) are drawn from the sermon in Albis (155r) and thus »in festo b. Thomae« (in the feast of Saint Thomas apostle) (294r). In the sermon "De una

14 I will refer to the modern foliation.

15 At times the mention is very short and difficult to interpret: "Sal salem [attrahit]. Dic de pignata multum salita" (Salt attracts salt. Tell of the very salty pot) (124v, Dom. in Albis). In other cases there is a sort of abstract: »Dic hic exemplum de illa muliere mortua que apparuit sacerdotibus quando officiabant eam sicut ponitur in legenda sancti Francisci (At this point tell of the anecdote of the dead woman who appeared to the priests as they celebrated the mass of suffrage, as reported in the legend of Saint Francis) (45v, dom. IIa post Octavam Epiph.) 
virgine " (for a Virgin) the four types of worldly love are distinguished, and to avoid repetition a reference to the sermon »De sancto Iohanne euangelista " is inserted: »Dic quomodo alibi habes " (Repeat what you find in another place).$^{16}$ It is a typical working instrument for preachers, and it is highly probable that the collection uses the materials of sermons actually delivered by Angelo da Porta Sole between Tuscany and Umbria. In the book of sermons, topics of searing political actuality in that geographical area in the decade 1320-1330 are dealt with and allusions to the physical reality, the geographical position ${ }^{17}$ and the cultural life of the communes are frequent. In some cases it can be supposed that the written sermon preserves the discourse delivered in a precise circumstance: the memory of the age in which Ambrogio Sansedoni joined the Order of the Preachers was immediately comprehensible to the public of Siena ${ }^{18}$ some sermons on peace probably concerned the great reconciliation that occurred in Florence on 2nd June 1327 with the mediation of Carlo di Calabria. ${ }^{19}$

In spite of the alternating of different copyists, the vernacular insertions and the same Latin context are characterised by linguistic traits of the Umbrian area. ${ }^{20}$ With reference to what will be said later in regard to the vernacular lexis, here it will suffice to recall that the Latin itself is penetrated by Umbrian phonetic traits. Hence, the reduction of the diphthong (luco for luoco) influences the Latin lucus in the sense of "luogo" (= place): "quia [apostoli] non inueniebant lucum « (142v); ${ }^{21}$ the transition from the intervocalic $-g$ - to the semivowel $-i$ - is seen in quadraiesima <QUADRAGESIMA ("in media quadraiesima " [midLent], fol. 110v), morieratus < MORIGERATU(M) (»mansuetus et bene morieratus", [meek and straight-laced], 291r), saita/saicta < SAGIPTA(M) ("mittebant saytas [...] saypte fuerunt peccata", [they launched arrows... the sins were arrows], 304r). ${ }^{22}$ The palatalization of the sibilant preceding the vowe ${ }^{23}$ is documented in conscilium (303r), conscilia (295v), alongside consilium (305r), consciliarius (305r) (»de principalioribus consciliariis« [one of the principal advisers]), consciderare (298r), conscideramus (299v) alongside consideramus (299v), desciderium (298r, 301v), descideria (294v), desciderat (299v, 301v, 302r, 305r).

16 Fol. 282v. In the margin there is the precise indication: »in .CCLXIIIJ. F.«.

17 Sermo 39 "Dominica IVa in Quadragesima«, fol. 108v: "Ciuitates in montibus hedificate et situate sunt saniores quam ciuitates que sunt hedificate in planitiebus [...] sicut uidemus manifeste in ciuitate peruscina et in Tuderto et etiam in Eugubio". (The cities constructed and situated on the mountains are more salubrious than the cities constructed in the plains [...] as can clearly be seen for Perugia and Todi and Gubbio).

18 Sermon »de sancto Iohanne euangelista« (262r): »Exemplum de sancto Ambrosio qui erat XIIIJm annorum quando intrauit Ordinem Predicatorum. Item exemplum de fratre Petro de Tarantasij qui erat eiusdem temporis quando intrauit Ordinem Predicatorum «. (Example of Saint Ambrose [of Siena] who was fourteen years old when he joined the Order of the Preachers. Add the example of Friar Peter of Tarentaise, his contemporary, when he joined the Order of the Preachers).

19 Cf. Dessì, Spectres du Bon Gouvernement, 117-118.

20 The treatment of the final $u$ excludes Perugia and refers back to the vernacular of the area to the east of the Tiber. Cf. Baldelli, Uso del volgare, 93.

21 Cf. Ageno, Lingua della cronaca todina, 173; Reinhard, Umbrische Studien; Ugolini, Annali e Cronaca, 292. See Iacopone da Todi, Laudi, ed. Ageno, 48, 17 »e ià mai non trovi luco«. (and you never have rest).

22 Delcorno, Tra latino e volgare, 36; Ageno, Lingua della cronaca todina, 197; Agostini, Volgare perugino, 137 ("quaraesima«).

23 Cf. Mattesini, Dialetti moderni e antichi, 180. The palatalization of the $s$ is moreover also diffused in other geographical areas. See Sella, Glossario latino emiliano, s.v. conscilium (Parma a. 1255). 


\section{Typology of the Bilingualism}

In his fundamental study on the macaronic English sermons Wenzel distinguishes between three types of linguistic blending, the first two in part motivated by the search for expositive clarity, while in the third type it presents itself as a sudden and unexpected change. ${ }^{24}$ The use of vernacular terms that do not have an exact Latin equivalent, the various forms of gloss, the insertion of proverbs, the translation of the auctoritates fall within the first type of alternation functional to the clarity of the communication; and to the second type is added the grid of the divisions and subdivisions of the sermon, which are quite often formulated in the vernacular in the Latin sermon books, while they are regularly in Latin in the Italian sermons. The third type of mixing of the languages is a switch from the Latin to the vernacular that concerns a group of words or whole phrases, and that occurs several times in the text. The book of sermons of Angelo da Porta Sole presents, with differing degrees of frequency, ${ }^{25}$ all of the macaronic elements indicated by Wenzel, except for the second type (the vulgarisation of the thematic verse and the use of the vernacular for divisions and subdivisions). Here I will only give a few samples of the first type, while my attention will be addressed more specifically to the third type. ${ }^{26}$

\section{Insertion of a Vernacular Term}

Single vernacular words are scattered in almost every folio of the codex. There is a clear-cut prevalence of nouns that are abruptly inserted into the context, interrupting the Latin sequence. Here is a reduced selection, arranged in alphabetical order:

Ismael fuit ciuis illius ciuitatis in qua semper est seruitus et angosc[i]a, scilicet ciuitatis inferni (Ismael was a citizen of that city in which there is perennial slavery and anguish, that is the infernal city) (108r)

Oportet quod [conuiuium] sit copiosum et habundans scilicet quod in conuiuio non sit solum de una bastiscione carnium, sed de pluribus. Or frater, de isto conuiuio uerum est quod fuit solum de una ambastiscione (It is necessary for the banquet to be copious and abundant, that is that there is not only a course of meat, but of many. Now brother, it is true that in this banquet there was only one course) (fol. 112v)

Uadit per tabernas et domos alienas sicut unus ribaldus et unus uilis baractiri (He goes to the taverns and the houses of others like a scoundrel and a despicable fraudster) $(44 \mathrm{r})^{27}$

24 Wenzel, Macaronic Sermons, 13-30 distinguishes between these three ways of mixing using the letters of the alphabet. In particular, for the use of vernacular vulgar proverbs in the Latin context, see, by the same author, French proverbs.

251.65 per cent is the proportion of the vernacular and Latin words in the De tempore cycle, and 1.40 per cent in the series of De sanctis. I have checked a sermon for Lent (First Sunday, fols. 5r-7v) and the sermon De sancta Lucia (fols. 257r-258v).

26 These observations are based on the perusal of the sermons from Advent to the Sunday in Albis (fols. 5-159r) and partially on the cycle De sanctis (fols. 254r-304r). The extended insertions, which implies several words, are recorded. Other vernacular elements are not considered separately: articles, prepositions, adverbs.

27 Iacopone da Todi, Laude, ed. Mancini, 57, 171 »O mondo baratteri« (Oh deceitful World); 74, 55 »Guàrdate da baratteri« (Beware of scoundrels). 
Sunt multi homines qui sunt ita stulti et grossi in conscientia quod credunt quod [...] uendere pannos ad credença plus quam ualeant propter indutias quas faciunt, credunt quod non sit peccatum (There are people so foolish and with a conscience that is so gross that, in their opinion, selling clothes on credit at a price higher than their value, owing to the deferral of the payment, is not a sin) (155r)

Item arengatores aliquando arengant et consulunt in consiliis quod fiat la cavalcata ${ }^{28}$ (Besides the political orators at times in the assemblies take the floor and advise attacking the enemy with the cavalry) (122r)

Exemplum de cercone ad uinum sed non de aceto ad uinum (Example: from the bad wine to the wine but not from the vinegar to the wine) $(145 \mathrm{v})^{29}$

Si haberet unum caput sicut unus cistone [...] talis persona non esset pulcra (If a person had a head like a large basket, that person would not be beautiful) (292v) $)^{30}$

Item si uellet discere artem texture oportet quod sciret quomodo ducitur drugdella ${ }^{31}$ per telam (Again if she wanted to learn the art of weaving it would be necessary for her to learn how the spool moves on the canvass) (257r)

Christus in resuscitatione Lazari uenit in amorem et famam et maiorem illuminan$z a$ apud populum Iudeorum quam per aliquod aliud miraculum quod fecerat inter eos (Christ on the occasion of the resurrection of Lazarus was loved and famous and enjoyed more fame among the people of the Jews than for any other miracle he had performed in their midst) (124v)

dicit euangelium in isto euangelio del nascimentu istius lucis (in this reading the Gospel tells of the birth of this light) (33v)

Pugna autem fit duobus modis: uel fugando hostem, uel arte et per maiestriam fugiendo hostem ut possit hostem decipere et colligere eum al passu in quo non posset se iuuare (The battle is fought in two ways: either by setting the enemy in flight or by fleeing before the enemy with artifice and ability such as to trick him and to surprise him in an ambush in which he cannot defend himself) (79v)

Ergo si illa que habemus a Deo habemus in prestança debemus ea dispensare secundum uoluntatem Domini cuius sunt (Thus if the gifts received from God are ours on loan, we must distribute them according to the wishes of God, to whom they belong) $(280 \mathrm{r})^{32}$

Cf. Testi trecenteschi di Città di Castello e del contado, ed. Agostini, Glossary, s.v. cavalcata »raids on horseback«.

Catanelli, Raccolta di voci perugine, s.v. cerquone »smell of bad wine«, and see Grande Dizionario della Lingua Italiana 2, s.v. cercone.

30 See Trabalza, Saggio di vocabolario, 14 s.v. cesta: "ave' la testa com'un cestone« (to feel one's head like a large basket).

31 Andrula, andrùola, andrùvola "spool of the loom« is a vernacular term of Todi. Cf. Mancini, Vocabolario del dialetto todino, 326. The term is also present in Giovanni Dominici, Lettere spirituali, ed. Casella and Pozzi, 58: "tesseralla colla indrudolla (she will weave it with the spool); Lettere spirituali, fol. 48v: »drudula overo navicella« (drudula that is spool).

32 Cf. Ugolini, Annali e Cronaca, s.v. prestança "prestito (loan)«; Agostini, Volgare perugino, Glossary, s.v. prestanza. 
Iterum quando despiciunt omnem personam nec uolunt stare ad conuersandum cum aliis, sicut multi cotali saltacchione hodie faciunt (Moreover when they despise every person and do not want to spend time speaking with others, as today many hypocritical saints do) $(157 \mathrm{v})^{33}$

Res trahit aliam rem per semelglanza (One thing attracts the other owing to their similarity) (fol. 124r)

propterea eodem panno [Christus] uestitus est cum homine et ad unam tagla uestiuit se cum eo ut omnem hominem peccatorem ad amicitiam suam attraheret (but Christ dressed in the cloth used by man and with the same style to attract every sinner to his friendship) (124r)

Item brachia eius fuerunt in cruce extensa sicut extenditur corda al uerrecelu (Moreover, his arms were outstretched on the Cross like the taut ropes of the winch) (138v)

La primavera letificat juuenes et senes [ms senex]. Vnde tunc senes cum uetule ac iuuenes uadunt in çurlu (Spring makes both young and old happy. Thus, the old men and women and the young feel like playing around) $(157 \mathrm{v}) .^{34}$

sicut uidemus in partibus ultramarinis ubi propter calorem solis inueniuntur omnes species nobiles et aromatice sicut cynnamomum ginçiber gariofoli nuces muscate çuccaru et omnes species uirtuose (as we can see in the overseas regions where owing to the solar heat we can find all the chosen aromatic spices like cinnamon, ginger, cloves, nutmegs, sugar, and every kind of effective spice) (278v).

They are terms that signify objects and working tools (cercone, cistone, drugdella, taglia, verrecellu, çuccaru), actions and specific techniques (bastiscione, cavalcata, credença, prestança, al passu), or social conditions (baractiri, illuminanza). Sometimes there are idiomatic expressions that have no Latin equivalent (in çurlu). In this case, the use of the vernacular contributes to the comprehension of the message. It alternates with Latin in an "organic" disposition, that is fully motivated. There are significant examples of this phenomenon already in some thirteenth-century sermon collections that had a limited dissemination. Ambrogio Sansedoni, well known to Friar Angelo da Porta Sole, compared the supreme virtue of charity with gualcatura, the last process of felt cloth production: "Caritas est complementum omnium bonorum sicut gualcatura est complementum panni« (Charity completes every good as fulling completes each cloth working). ${ }^{35}$

34 See other examples: "In tempore primi ueris [...] omnes homines tunc gaudent et cantant et senes omnes uadunt in çurlu (fol. 26or), etiam senes uadunt in çurlu (fol. 267r)« (In spring everyone has fun and sings and all the old people ramble]. Zurlo/zurro »wanting to fool around « is documented in texts of the XV century: Burchiello, Pulci). Entrare in zurlo (di qualcosa) "feeling like, desiring «. Cf. GDLI, s.v. zurlo. Not to be confused with zurlo "spinning top«, documented in the medieval Latin (XIV century Treviso), cf. Sella, Glossario latino-italiano, s.v. ludus (p. 336) ludus ad zurlos "spinning top game."

35 Siena, Biblioteca Comunale, MS T IV 7, fol. 45r (Delcorno, Tra latino e volgare, 33). 
Less frequent is the use of the vernacular in the verb forms:

Omnes Egyptii fuerunt cooperti aqua maris et mortui sunt omnes in mare et annegaro (All the Egyptians were submerged by the water of the sea and they all drowned to death) (131r)

Iudei nolebant credere Christo nec uolebant eum audire, odiebant et diffamallu (the Jews did not want to believe in Christ and did not want to listen to him, they hated him and slandered him) (118r)

[Laborator] quando uidet mensam parari et cibum paratum ad commedendum mul-

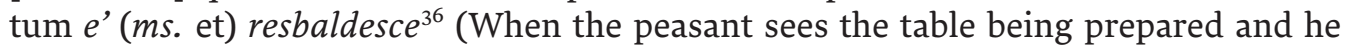
sees the food ready to eat he becomes very happy) (110r)

misit diluuium in mundum et subtrassit et negauit et subissò totum mundum. (He sent the Flood upon the earth and sank and drowned and submerged the whole world [71r]).

The vernacular rarely brushes the adjectival forms:

Unde nullus christianus da bene deberet esse qui in isto festo non haberet plures pauperes in domo sua (Thus in this feast there should be no good Christian who does not welcome many poor into his house) (26v)

[Prima amicitia] est infirma et uana [...], secunda est falsa et peruersa et fallace et ista uocatur amicitia mundana. Tertia est bona recta et verace (The first friendship is unstable and vain, the second is false and perverse and treacherous: this is called worldly friendship. The third is good, righteous and true) (50r)

[Symon] dicebat quod Magdalena erat una et malvascia et publica peccat[r]is (Simon said that Magdalen was a bad woman and a public harlot) (140r)

Tales ponunt eum [Deum] in loco sconuenevile (Some put it in a place that is inconvenient/undignified) (87v).

\section{Glosses}

The gloss, introduced by multiple formulae, is an essential and diffuse procedure of medieval predication, which is the instrument of cultural mediation, acting as a bridge between Latin and lay culture. ${ }^{37}$ Suffice it here to mention with a few examples the presence of this linguistic element in the books of sermons of Angelo da Porta Sole. Sive, idest, hoc est, scilicet are the most frequent signs of the gloss. ${ }^{38}$ The equivalence is, in general, established between Latin and the vernacular:

36 Cf. Iacopone da Todi, Laudi, ed. Ageno, 43, 111: »tutta la corte farai resbaldire« (all the court you shall make merry) (resbaldire "make merry, Provençal e s b a u d i r»). See GDLI, s.v. risbaldire "make merry."

37 According to a very ancient usage, present, for instance, in the juridical literature. See Avalle D'Arco, Parodia.

38 The simple adjacency of the two terms is not frequent: "Arbor habet radices lu pedale (The tree has roots, the foot) (fol. 140v). 
uentosa siue coppa (suction cup, that is cupping glass) (125r), impellit hominem siue lu sforza ad bene operandum (pushes man, that is forces him to do good) (103v); mediator idest intrameççadore (mediator, that is he who is in the middle) (116r); Vnde benignitas nichil aliud est quam bona ignitas hoc est bona caldeçça demonstrata in opere exteriori (Where by benignity is meant good inflammation, that is good heat that is demonstrated in the outer deeds) (54v); uocatur ypopanti hoc est dicere unu scuntramentu (is called ypopanti, that is an encounter) $(56 \mathrm{r})^{39}$; infrigidare scilicet $d i$ fare fredda la cosa (cooling, meaning making something cold) (74v); [Christus elegit] conueniens tempus scilicet tempus de la primauera (Jesus Christ chose the suitable time, that is the time of spring) (83r).

But the opposite may also be true: persona scolorata siue ialida (colourless, yellow person) (292v)..$^{40}$

This style of didactic explanation is frequently used in Latin sermons and in some other middle Latin texts. Federico Visconti, Bishop of Pisa (1253-1277), introduces in his sermons the vernacular gloss of some Latin words: regula sive riga, in intecula sive in lucedula que vocatur lucciola (line or regula, in firefly which is called lucciola). Yet sometimes he proceeds in a different way: first he introduces a vernacular word adapted to Latin morphology and then he explains it with a proper Latin term. Hence the term for wick (which in Italian is stoppi$n o$ ) is indicated as "stuppinum sive licinium ${ }^{41}{ }^{41}$ The second type of gloss is very frequent in the Cronicle of Salimbene de Adam and appears, though rarely, in the sermons of Anthony of Padua. ${ }^{42}$

Well known and frequent is the gloss in the form of a dittology, variously defined by the scholars. ${ }^{43}$ Angelo da Porta Sole very often resorts to this procedure; here we shall only provide a reduced exemplification. The dittology first and foremost concerns adjectives:

GDLI, s.v. scontramento »encounter«, with examples of Giamboni, Cavalca.

40 Occasionally the equivalent middle Latin term is introduced by sive: "[Pictor] tabulam siue assidem parat « (The painter prepares the table, that is the wooden board) (17v), »ex tibya tortua siue coxa « (from the contorted tibia, that is the thigh) (19r), »fecit septem pallas siue gumfos niuis " (made seven balls, that is snowballs) (150v); or, by contrast, the classical word is added: "aliquod fedum siue donum « (some feud, that is gift) (3oor). See also the isolated case with scilicet: »loturis putridis scilicet goesa (?) et banbascillo« (with putrid washes, that is with ? and cotton wool) (71r).

41 Delcorno, Tra latino e volgare, 33; Federico Visconti, Glossaire, s.v. lucedula, riga.

42 Bourgain, Analyse linguistique et stylistique, 129.

43 "sinonimia glossante (Lausberg, Elementi di retorica, par. 284), "coppia sinonimica« (Lazzarini, "Per latinos grossos«, 309), "glose en reduction« (Buridant, Binômes synonymiques, 28), »etymological doublets« (Wenzel, Macaronic Sermons, 86). 
diues et asciatu (rich and well-to-do/well-off) (112r), diues et adasciato (rich and very well-to-do) $(302 \mathrm{v}),{ }^{44}$ dimictere diuitem et bene adasciatu (release the rich and wellto-do) (86v), grati et conoscenti (grateful and acknowledging)) (fol. 11v), displicibilis et esgratiatu (unpleasant and undesirable) (269v), nimis audaces et troppu fro[n]tati et paççi (too bold and too brazen and mad) (157r), leues et ligeri (slight and light) (300v), ${ }^{45}$ facies quasi nigra et oblivengna (face almost black and olive) (100v), ${ }^{46}$ manifestum et palese (evident and manifest) (56v), mala et malvascia (bad and wicked) (284r), iniqui et malvasi (bad and wicked) (287v), ${ }^{47}$ stultus et pasciu (foolish and mad) (91v), totus calidus [ms callidus] et tuctu sbolgentatu (all warm and boiling hot) (131r) ${ }^{48}$;

and verbs:

[merchatores] oculos hominum cecant et abarbagl[i]ano (the merchants blind and dazzle the eyes of men) (93v), sum uictus a te et abbactutu (I am won over by you and fallen) (98v), ${ }^{49}$ eos debellabant et abattielli (they defeated them and struck them down) (150v), gaudete et alegratevo (enjoy and make merry) (110v), uerberatus et bactutu (whipped and beaten) (133r), Ite maledicti et siate maledicti (go ye accursed and be damned) (157r), destruere et subissare (destroy and die from shame) (106v).

Also very frequent is the dittology that clarifies the meaning of a noun:

magnam uilitatem et grande abbassamento recepit (underwent great spite and great humiliation) (125r), ${ }^{50}$ non curauit alio sponso nec d'altra amança [...] nisi solum de sponso et amança sua paradisi (he wanted no other spouse or other lover if not the spouse and his lover of paradise) (289v), ${ }^{51}$ quidam stultus et unus barnabese (a fool and an idiot) (270r),,$^{52}$ unus ribaldus et unus uilis baractiri (a ribald and a worthless fraudster (44r), letitia et delectamentu (joy and delight) (302r), inte[m]ptio sua et $l u$

44 See Iacopone da Todi, Laude, ed. Mancini, 75, 27-28 »Or vedete el guadagnato/ come sso' ricco e adasciato « (Now look at the gain, how rich and wealthy I am).

45 Just above, in the same passage »leues et lieri«.

46 See GDLI, s.v. olivigno »olive-coloured«.

47 Another example in fol. 296v: "iniqui et maluasci homines«. Cf. Iacopone Laude (ed. Mancini), 11, 35: "quella malvascia schera" (that evil rabble).

48 In the Cassinesi glosses to the Carmen Pascale of Sedulio we can find flagrantes »sbolentanti«. Cf. Baldelli, Glosse in volgare cassinese, 65 .

49 Oft-repeated formula: "debellat et abbacte« (defeats and throws to the ground) (259v), "fuit a diabolo uictus et abactutu (was defeated and felled by the devil) (287r), »uicit et abactette omnes illos sapientes [...] uicit et abacteo dyabolum « (defeated and overcame all those sages ... defeated and felled the devil) (290v).

50 Just below: »in signo humilitatis et maximi abbassamenti« (in a sign of humility and utmost weakness) (125r). See Iacopone, Laude, ed. Mancini, 86, 103-104 "a tale abassamento/Iesù, tu se' venuto?« (Jesus, you have reached such a humiliation?) (and Glossary).

51 Lyrical terms of Provencal origin, several times in Iacopone, Laude (see Glossary).

52 Perhaps it can come close to the modern bernogio »stupid«. Cf. Catanelli, Raccolta di voci perugine, 43. 
entendimentu suum (the object of his attention and his love) $(298 \mathrm{v})$, totum cor suum et lu entendimentu (all his heart and his love) (30ov), ${ }^{53}$ libertas et francheza (freedom and independence) (108r), ${ }^{54}$ per rapinam et malletolto [malleloto MS] (for theft and unlawful gain) (154r), multe feditates et multe cose sconvenevile (many indecencies and many shameful things) (93v).

It is remarkable that in some cases, through the use of dittology, the classical Latin is explained with the medieval Latin, which coincides, except for the flexion, with the vulgar tongue: that is, a macaronic Latin in the proper sense. ${ }^{55}$ This phenomenon appears very frequently in the sermons of Angelo di Porta Sole, which here can be documented with a few examples. Among the most frequent cases are the noun pairs. They usually precede the classical form (as already seen above in the series of Latin terms glossed in the vernacular). On the contrary, see the following examples:

per doctrinam et per admaiestramentum (by means of doctrine and teaching) (289r), ad resistendum latronibus et ascaranis (to withstand the thieves and the bandits) (279r), facit equum de canna et de bastone (makes a pony with a cane and with a stick) (272v) ${ }^{56}$ labor et briga (effort and difficulty) (285r), pro consiliis et brigis (for advice and disputes) (275v), habitaculum et cammera (habitation and chamber) (291v), faciebat fiscellas et sportillas ${ }^{57}$ (made hampers and baskets) (263r).

However, often the order is the opposite, preceding the middle Latin term: ${ }^{58}$

ascarani et multi latrones (brigands and many bandits) (24r), ${ }^{59}$ ex superfluo ascio et otio corporali (for excessive well-being and corporeal idleness) (94r), facit cupam siue calicem (makes a cup or chalice) (265v), per percussiones martellatoris siue fabri (by means of the blows of the one who handles the hammer that is the blacksmith (295v), ad omnem rischium et omne periculum (at every risk and danger) (287v).

53 They are words proper to Jacoponic poetry. See Iacopone, Laudi, ed. Ageno, Glossary, s.v. delettamento, entennemento.

54 The suspicion remains that it is a middle Latin form in the passage that follows right afterwards: "quod [ciuitas] sit libera et franca« (that the city shall be free and independent) (108v).

55 Cf. Paoli, Latino maccheronico, 54-55 quoted in Lazzerini, »Per latinos grossos...«, 230 n. 2. A survey of the macaronic literature in Segre, Tradizione macaronica da Folengo.

56 Sella, Glossario latino emiliano, s.v. bastone, bastonus.

57 Sella, Glossario latino emiliano, s.v. sporta.

58 The same order can be noted in a passage where vernacular terms recur deriving from different levels of Latin lexis: "in qua ciuitate erit un giardinu et un ortu plenus arboribus" (city in which there will be a garden and a vegetable plot full of trees) (148v). See Sella, Glossario latino-italiano, s.v. zardinum.

59 A form also present in Umbrian texts. See Iacopone, Laudi, ed. Ageno, 58, 14 "come ascaran rapire (to rob as a scoundrel); Agostini, Volgare perugino, Glossary, s.v. ascarano. 
The classical word precedes the vernacular in the dittology of the adjectives

sapientes et adveduti (wise and shrewd) (154r), profundum et cupum (profound and sullen) (293v), expulsi et exba[n]diti (expelled and bandit/exiled) (292r), ${ }^{60}$ pauidi et codardi (fear-stricken and cowardly) (287v), timidus et codardus (timid and cowardly) (294v);

but there is no lack of cases in which the middle Latin term occurs first:

arditi et audaces (daring and brave) (287v), bene assiduatus et bene positus (well situated and well founded) (272r), probus et ualens (valiant/courageous and strong) (294v), contempti et consolati (content and consoled) (8v), prona et parata (willing and ready) (120v). ${ }^{61}$

The same variation in the succession of terms can be observed in the use of the verb pairs, where the classical word usually precedes the middle Latin term:

mortificare et abbactere (dishearten and bring down) (306v), fuit uilificatus et abbassatus (was despised and humiliated) (40v), ordinauerunt et stantiauerunt (ordered and arranged) (122r), lauant se et stensciant se (they wash themselves and remove their make-up) (108v), ${ }^{62}$ se lauare et strunciare (wash and rub themselves) (71r). ${ }^{63}$

But notice contextually »conseruare et manutenere" (preserve and maintain), followed by "manutenere et conseruare« (maintain and preserve) (301v). ${ }^{64}$

\section{Switch}

Code-switching concerns only a part of the sermons and is more frequent in De tempore (fols. $5 \mathrm{r}-252 \mathrm{v}$ ) than in the series about saints (fols. 254r-327r). Six sermons out of the first ten of $D e$ Tempore, compared to two from the first ten sermons De sanctis, show important evidence of switching. The extended mixture of Latin and the vernacular is considerably inferior to the continuous insertion of single Italian words and glosses, as exemplified above. It is noteworthy that no marks distinguish the vernacular words, as if the preacher (and the copyist) did

60 A form continued in the vernacular. See Ugolini, Annali e Cronaca, Repertorio lessicale s.v. esbandite »sbanditi«; Iacopone, Laudi, ed. Ageno, 43, 252 »che esbannito fo de sua contrata (who was exiled from his country), and see Glossary, s.v. esbannito, esbannita.

61 In the same place "prontum et paratum « (ready and willing) (120v).

62 GDLI, s.v. stingere "clean a stain« (Dante, Purgatorio, I 96 "sì ch'ogne sucidume quindi stinghe«), (to wipe all traces of defilement from it [from the face])

63 GDLI, s.v. strusciare 3 »frizionare una parte del corpo [...] per il trucco« (rubbing a part of the body [...] for the make-up). Strecciata »rub (»dasse 'na strecciata «) is recorded in Trabalza, Saggio di vocabolario, 39. Strucciare "sgranare, macellare" (shelling, butchering) in Mancini, Vocabolario del dialetto todino, s.v.

64 "nitantur carcerem et uitam corporis [...] conseruare et manutenere ne carcer, scilicet uita corporalis frangatur et deficiat [...] Quandocumque studet homo eam manutenere et conseruare oportet quod pur deficiat et moriatur" (make the effort to keep safe the prison and the corporeal life and to maintain it so that the prison, that is the corporeal life, breaks and ends. However much one tries to sustain it and preserve it, it must eventually cease and die) (fol. 301v). 
not perceive a strong difference between Latin and Italian. Although the linguistic change is free and unpredictable, it can be noted that it recurs frequently in some conditions. The vernacular insertion highlights the vivacity of the direct discourse in the "dialogic " context of the face-to-face encounter between the preacher and the public. At times the preacher faithfully reports the comments of people far removed from the sermon, almost a third interlocutor:

Item dicunt peccatores mundi: [...] Quare fecit [Deus] pulcras mulieres, pulcros pannos scilicet scarletum, brunetum et alios pannos diuersorum colorum? [...] Certe ad hoc ut homo delectaretur cum pulcra muliere et haberet solatium cum ea, et in solatiis scilicet mundum fecit, etiam pulcros pannos ut homo uestiret se de eis et goddessene et auessene bene (Moreover, the worldly sinners say: Why did God make beautiful women, nice clothes, meaning scarlet, brown and other clothes of different colours? Certainly for this purpose, that man should get pleasure from the beautiful woman and amuse himself with her, and God has made the world to enjoy it, and the nice clothes so that he may wear them and enjoy them and draw benefits from them) (85v)

Hic possetis michi facere questionem et dicere: »Or frater, pur est uerum illud quod dicunt homines de lo destinatu«. Consueuerunt enim dicere homines mundi: "Poi k'è destinato la cosa ala persona, no la pote fugire né schifare et è besogno [besiogio MS] ke chosi sia" (Here you could ask me a question and say: Now, friar, it is really true what they say of fate. The worldly ones indeed are used to saying: As each person has his destiny, he can neither escape nor avert it, it is necessary for it to happen) (90r).

Multi dicunt: Frater, nolo facere penitentiam né avere male nec affligi (Many say: Friar, I do not want to pay penitence nor have suffering nor affliction) (101v)

Vnde [peccatores] dicunt: Dimittamus dicere istos predicatores qui dicunt quod faciamus penitentia et quod affligamus nos in mundo isto, quia uerba eorum sunt truffe et buffe et ki à bene en quistu mundu sì à bene ne l'altru (Thus the sinners say: Let these preachers that preach pay penitence and afflict us in this world; their words are deceitful and fables and whoever enjoys himself in this world will have goodness also in the next world), (281r).

The linguistic shifting from Latin to the vernacular occurs in the sermocinatio, that is, a fictitious question proposed by the audience and the answer of the preacher. In this case, by reserving the vernacular for the audience, the alternate use of Latin and the vernacular points out the different culture of the interlocutors, with an effective rhetorical function. ${ }^{65}$

At times the preacher reports the "voices" exactly, the slogans shouted in the streets. So it is in the sermon for St John the Evangelist, where a form of love similar to madness can be distinguished:

65 On the sermocinatio, a rhetorical figure widely employed in Augustin's sermons, see Delcorno, Tra latino e volgare, 77 n. 154. 
Sic inuenimus exemplum de Sperandeo et Sperandea qui ibant per ciuitates et uillas clamando sicut fatui Ihesu Christo, Ihesu Christo et expoliabant se tempore maximi frigoris et mittebant se in flumine. Item Sperandea [...] clamabat Laudatu et benedictu sia Ihesu Christu. Et totum istud procedebat ex amore diuino (So we have the example of Sperandeo and Sperandea [nickname: Hope in God] who went to towns and villages shouting like lunatics Jesus Christ, Jesus Christ and they stripped naked when the cold was most acute and they jumped into the river. Moreover, Sperandea shouted Praised and blessed be Jesus Christ. All this originated from the love of God) (262v).

The linguistic change has a definite function in the enactment of the evangelic episodes and in particular in the sermons of the Holy Week, which paved the way to strongly emotional episodes ${ }^{66}$ The sermons of the Holy Week were a crucial opportunity to present the Gospel in a dramatic form. In particular, the sermon for Good Friday elicited the emotions of the hearers in order to move their hearts to contrition and reform of their moral behaviour. The liturgy and the religious drama are the sources of the preaching style. Moreover Friar Angelo probably imitates the "lauda drammatica" performed by the confraternities of Perugia, inspired by the Order of Preachers. ${ }^{67}$

Hence, in the Good Friday sermon the preacher effectively imagines the voices of the Jews who accused Jesus:

Maledicti Iudei accusabant Christum ante Pilatum [...] et dicebant Questu è maluasciu et unu reo homo qui sabbatum non custodit (The accursed Jews accused Christ before Pilate and said This is a wicked and guilty man who does not observe the sabbath) (137r);

or the mockery of the soldiers who taunted him:

Aue rex Iudeorum [...] qui se dicebat prophetam missum a lege [...] et non congnoscit illos qui percutiunt eum. Or ecco bon rege, or ecco bon propheta, or ecco figlio [ms filgo] de Dio! Qui ita flagellatur et uerberatur et non potest se iuuare et defendere a nobis« (Hail king of the Jews, he who said he was sent according to the Law and does not recognise those who beat him. Here good king, here good prophet, here the Son of God! He who is struck and scourged like this and can't help himself and defend himself from us $(137 \mathrm{v}){ }^{68}$

66 Wenzel, Macaronic Sermons, 66: »It is thus fair to say that the Sunday of Lent, Good Friday, and Easter were favorite occasions for the production of linguistically mixed and, especially, fully macaronic sermons«. See also Bériou, Latin and the vernacular (with an appendix of unpublished texts); Johnson, Grammar of Good Friday.

67 The Dominicans of Perugia invented a lyrical type of poetry (lauda) that was a kind of translation and explication of the evangelical story: a good example is the extended lauda Segnore scribe or que fecemo (Honourable scribes, what are we doing?). Cf. Baldelli, Lauda e i disciplinati, 355 and 342.

68 See also fol. 141r "Et credite bene illi quod ipse sit Filius Dei et andateli bene direto (And believe well him that he is the Son of God and continue to follow him). 
The insertion of dialogic remarks in the vernacular also highlights some exemplary stories:

exemplum de quodam milite regis Anglie [...] quando inducebatur a fratribus ut confiteretur respondebat et dicebat: Non possum adhuc dimittere istud [...] lassateme stare mo', bene confitebor (Here is the example of a knight of the king of Anglia, who, when the friars warned that he should make his confession, replied and said: Now I can't abandon that [the sin], now let me be, I shall make my confession later) (9r). ${ }^{69}$

Here the irrruption of the vernacular shows a scenic performance, a mimicry that highlights the oral performance (procédé d'oralisation), and enlivens the exemplary story. ${ }^{70}$

Similar to those variations are the glosses or rather the insertions of direct speech introduced by the formula "quasi diceret ${ }^{.1}{ }^{1}$ The vernacular locution usually introduces a paraphrasis of the biblical passage, almost a translation of the auctoritas in a more simple and domestic language:

propterea dicit "Querite Dominum dum inueniri potest " (Is 55,6), quasi diceret: $\mathrm{Si}$ gnori, seruire et andare po 'I Signore est multum facile et multum asceuile (Seek the Lord while he lets himself be found, as though wanting to say: Sirs, it is very easy and convenient to serve and follow the Lord) (86r)

Ecce consolatio quam faciebat ei uxor sua: "Amen, dicebat, o stulte et bestia, de quo benedicis et regratiaris Deo? « [...] Vnde dicebat: "Benedic Deo et morere« (Iob 2,9) quasi diceret: Maledic et lassate morire (Here is the consolation that his wife gave to him: "Amen, she said, oh fool and beast, what do you bless and what do you thank God for? And she says: Bless the Lord and die, as if to say: Damn him and die) (89r)

Dicens [Christus]: "Non sum missus nisi ad oues que perierunt domus Israel" (Mt 15,24). Quasi diceret: Statevo in pace, non rogetis me pro ea (And Christ said: I have been sent only for the sheep of the house of Israel, which were lost. Almost as if to say: Rest assured, do not pray to me for her) (98r)

Propterea dixit beatus Petrus«Domine, faciamus hic tria tabernacula« (Mc 9,4), quasi diceret: Domine[...] nunquam recedamus ab inuicem et semper stemus in mundo isto et auiamone bene et godiamone assieme (And so Saint Peter said: Lord, let us put up three tents here, as if to say: Lord let us never separate, and let's stay in this world and take what is good and enjoy it together) (99r)

69 Add to this the dialogue between the soul and the body: »Vnde dicit corpus anime: [...] habeamus aliquantulum de bono in mundo isto et gaudianne una peç̧a (And says the body to the soul.... Let's take some wellbeing in this world and enjoy it for a long time) (5v-6r); the monologue of the rich merchant: "Ibo in Lombardiam, in Franciam et ultra mare et per talem modum potero ditari et emere tales possessiones de cotal miu vicinu« (I shall go to Lombardy, France and overseas and so shall be able to get rich and buy the properties of my neighbour) (6v).

70 Polo de Beaulieu, Formes dialoguées: Introduction, 16 n. 22: »j'ajouterais pour les recueils d'exempla en latin, la rupture linguistique avec l'irruption de la langue vernaculaire sous forme d'une expression isolée, d'un proverbe ou de répliques plus développées (As to the Latin collections of the exempla, I would add the breaking of Latin produced by the irruption of the vernacular in the form of an isolated term, a proverb or more extended answer «).

71 Less frequently »hoc est«: »Item homo consueuit uincere aduersarium bono munimine, hoc est quando est bene armatus de bone arme" (Man is also used to defeating his adversary with a good protection, that is in being well equipped with good weapons) (10v). 
propterea dicit ipse Dominus Iudeis sauferetur a uobis regnum Dei et dabitur genti facienti fructus eius" (Mt 21, 4) quasi diceret: O miseri Iudei, ego derelinquam uos, sed male a lu uostru opu quia dispergimini (Thus the Lord said to the Jews: You shall be stripped of the kingdom of God and it will be given to a people that will make it bear fruit, as if to say: Oh wretched Jews, I will abandon you, but for your misfortune because you will be scattered) (120r).

The linguistic change is often used to obtain an effect of reality in the stories and in the frequent references to daily experience. The linguistic variation mostly involves the verb:

Vnde [peccator] labitur et cadit de peccato in peccatum et va tramaççando sicut cecus absque luce (Thus the sinner wavers and falls into sin and gropes around like a blind man in the darkness) (40v)

Si filius non est gratus né conoscente ita quod turbetur et altercetur cum matre, uerberat eum et scarmiglalu finamente (If the son is ungrateful and unrecognising to the point that he gets angry and fights with his mother, she gives him a good beating and scolding (56v)

[Nero] acuit unum palum ligneum et ipsum appodiauit ad quandam rupem et stroppòsi in questo palo (Nero sharpened a wooden stake and leant it against a rock and killed himself against this stake) (123r-v)

[Iuuenes] uadunt cantando cum istrumentis et faciendo le matinate la nocte (the young go singing with musical instruments and go serenading by night) (157r)

Vnde uidetis quod quando incipit uenire febris infirmus bacte li denti (You see then that when the fever starts to come the sick person's teeth start to chatter) (306v).

At times, instead, the vulgar insertion highlights the mode of action or an object:

[aues] semper uadunt mouendo se et uolando intro per la cabia (the birds move relentlessly and fly inside the cage) (39v)

[Bichine] uolunt portare [...] mantellum et tunicam camelinam cole corde pendente (the Beguines wear the cloak and the tunic made of camel hairs with hanging elements) (70v)

Quare reseruauit signa plagarum suarum et dele ferite ch'egl'ebbe nel corpo suo? (Why did he preserve the signs of his sores and the wounds that he received on his body?) (143v).

Of great rhetorical efficacy are some rare intrasentential insertions in the vernacular, where the attention to detail functions to introduce a pathetic effect, also underlined by the use of the exclamations at the end or at the beginning of the passage: 
Quando filius eius est paruus tunc [rusticus] dicit ei: Inperatore miu, rege miu! Tunc enim uestit eum de bellu uirgatu et facit ei pulcros calcios et pulcram corrigiam. Sed uidete quomodo mutatur cantio, quia quando est magnus uestit eum de lacçu ${ }^{72}$ et fali unu guacçarrone ${ }^{73}$ et pòlli la sappa ${ }^{74}$ in manu et aliquando la vanga. Or ecco bellu rege et bellu markese! (When his son is small the peasant tells him: Oh my emperor, my king! So indeed he dresses him in fine lined cloth and he makes him good shoes and a fine belt. But you see how the song changes: when his son becomes an adult he dresses him with coarse cloth and makes him a shirt for work and puts the hoe in his hand and at times the shovel. Now see what a fine king and what a fine marquis!) (57r).

Et uidete impietatem et crudelitatem! che li panni de gamba no gli lassaro conciossia cosa che la camiscia e' panni de gamba et aliquando una gonnellecta sì ène lassa ad li malefactori et latroni (And you can see what impiety and what cruelty! They did not even leave him his underpants, even if the wrongdoers and the bandits keep their underclothes and at times a small skirt) (140v-141r). ${ }^{75}$

From the Latin there is a shift to the vernacular in the case of imaginative and proverbial expressions that do not have a straightforward Latin equivalent: ${ }^{76}$ The preachers of the thirteenth and fourteenth centuries, for instance Ambrogio Sansedoni, Federico Visconti and Giovanni da San Gimignano frequently quote proverbs and proverbial expressions both in Latin and in the vernacular. ${ }^{77}$ This habit was diffused from Paris, almost as a fashionable element imposed, according to prominent scholars, by the authoritative model of Wilhelm of Auvergne, Bishop of Paris (1228-1249). Thus, the clergy created "a sort of cultural complicity with the audience«, as they exposed in a simpler way the fundamental contents of the Christian theology. ${ }^{78}$

72 Cf. Mancini, Vocabolario del dialetto todino, s.v. lazzo "stoffa ordita di pura lana o di puro cotone« (cloth woven from pure wool or pure cotton).

73 See Trabalza, Saggio di vocabolario, s. v. sargone, vazzarone, guazzarone "specie di camicia di panno grosso con buchi laterali e scollata, che tengono esternamente i contadini e i potatori per salvare i vestiti dalle sdruciture che potrebbero produrre le spine, gli sterpi o le frasche« (sort of shirt made of thick cloth with holes at the sides and collarless, which the peasants keep externally and the pruners to save their clothes from the tears that could be caused by thorns, brushwood or boughs).

74 See Agostini, Volgare perugino, 131 (sappa) e sapare in Testi trecenteschi di Città di Castello e del contado, ed. Agostini, Glossary, s.v.

75 Cf. Delcorno, Tra latino e volgare, 38-39.

76 Cf. Wenzel, Macaronic Sermons, 100: "phrases peculiar to the vernacular for which an exact or even approximate counterpart in Latin would have been hard to find«.

77 Delcorno, Tra latino e volgare, 31-32.

78 Guillelmi Alverni Sermones de Tempore, XXXI. 
[Caro] obscurat intellectum hominis in peccatis faciendis et fali vedere la luna per l'acqua [...] Sic facit caro anime demonstrannoli la luna per l'acqua (The flesh obscures man's intellect when he commits the sin and shows him the moon reflected in the water/the moon in the well ... So does the flesh showing to the soul the moon in the water) $(5 v)^{79}$

eundo moritur et vasene ad casa calda (on the journey he dies and goes to hell/to the hothouse) $(6 \mathrm{v})^{80}$

recte Dominus Noster se fa orecle de mercatante (rightly Our Lord turns a deaf ear) (51r)

non est mulus nec leo [...] ket non desse li maiuri calci ket potesse (there is no mule or lion that would not issue the hardest kicks it possibly could) (55r)

[homines seculares] dicunt: Questu è tal uinum che parlla coll'angeli (the worldly men say: This is a wine so good that it gets along with the angels/it is worthy of the angels (72r)

In quantum reuelat amicus alteri amico uidetur sibi quod alleuietur [tribulatio] quia allora si ssi vapora de la tribulatione sua et passasi (Suffering, being the friend that confides in the friend, is alleviated because then he lets his tribulation fade away and he consoles himself) $(75 \mathrm{v})$

Vnde homo superbus et uanagloriosus semper habet uentum in auribus et semper $l i$ çiffila l'orecchie (Whereupon the conceited and vainglorious man always has the wind in his ears and his ears will always whistle) (281r). ${ }^{81}$

By contrast, the author resorts to stereotyped and almost obligatory expressions, albeit far from having any rhetorical effect:

Vnde hodie per la mala nostra ventura [...] per mundum committuntur multa mala (Whereupon today for our misfortune many evils are committed in the world (40v)

Mortem ego substineo pro amore hominis per meam propriam uoluntatem, non per forza (For the love of men I bear death of my own will, not forced to do so (128v).

Corpus glorificatum [...] erit ad unum battimentu de ochuli subito quando uolent ultra mare siue in Francia (The glorified body will be across the seas or in France in the batting of an eyelid, according to the will of the blessed (149v).

79 Probable allusion to the fable of the moon in the well, which was widespread among the preachers. See Sancti Antonii Patavini Sermones dominicales et festivi, ed. Costa et al., 2, 179-180.

80 Idiomatic expression very frequent in the preaching of Bernardino da Siena. Cf. Prediche volgari sul Campo di Siena (1427), ed. Delcorno, pred. X, 82. »il diavolo prese quella anima e portolla a casa calda (the devil took that soul and took it to the hot house). Other examples XIV 20, 30; XXXI 13, 24; XXXVIII 21; XLIII 114; XLV 39.

81 Such expressions at times take the form of similitude. See sicut una capra scorticata (like a skinned goat) (292v). 
Although, as has already been pointed out, Angelo da Porta Sole does not use the vernacular to utter the divisio of the sermon, ${ }^{82}$ he often draws attention to the parts of the argumentation or to content of particular importance, moving from Latin to the vernacular:

Hoc ostendo uobis per tre belle rasconi (I will demonstrate all this for three valid reasons/arguments) (5r)

[Hoc] uolo uobis ostendere et demostrare per IIIJor belle rasioni (What I want to show you and demonstrate for four good reasons) (303v).

The linguistic change is a signal to highlight a moment in the sermon in which the exchange between the listeners is more direct. Note that Angelo da Porta Sole very frequently uses the allocution Signori, which probably derives from a jesting tradition, and introduces an oral movement in the text. The Ritmo Cassinese, composed in the last years of the twelfth century, employs this apostrophe, ${ }^{83}$ and the expression appears in the beginning of some popular jest compositions of the fourteenth century: ${ }^{84}$

Or, signori, ad hoc respondeo uobis, ore attendete bene (Now, sirs, on this matter I will answer you, now pay great attention) (17r)

Or ad istam beatitudinem docet nos apostolus Iohannes in epistula hodierna in che modu nos possumus ire (Well then, the apostle John in the epistle that is read now shows us in what way we can go in this beatitude) (284r).

The reminder of the central point of the sermon can be reinforced by a sentence:

Or uidete, signori, quomodo consilium istud processit ex mala operatione, quia Christus per bene fare recepete male (Now see, sirs, how this decision came from a bad action, as Christ having done good got evil in return) (122v).

Almost symmetrically, the conclusion of a part of the sermon is formulated in the vernacular or as a reflection in a phrase that sums up a more detailed treatise:

Et sic uidetis quantum periculum contigit de loturis et ornamentis et de mali portamenti de le femine (And so you will see how much danger occurs because of the lotions and ornaments and the misconduct of women) (71r);

82 A trace of this use persists in the sermon »In Annuntiatione«: "Primo dico quod ista anbasciata est commendanda et laudanda per lu tempu conueneuele in quo fuit facta (First of all, I say this message [the Annunciation of the Virgin Mary] is to be appreciated and praised owing to the convenient time in which it was made) (267r).

83 A sort of clerk-jest addresses the audience saying: Eo sinjuri, s'eo fabello,/lo bostru audire compello (Sirs, I speak to you; I ask for your attention).

84 See, for instance, Matazone da Caligano (Nativitas rusticorum et qualiter debent tractari [The origin of the villains and how to treat them]): A voy, segnor e cavaler/ sì llo conto volonter (To you, lords and knights I will speak willingly], or the anonymous Rainaldo e Lesengrino: Segnori e done che sé' qui (Ladies and gentlemen who are gathering here); cf., Poeti del Duecento, ed. Contini, I, 9, 791, 811; Antologia della poesia italiana: Duecento, ed. Segre and Ossola, 10 (Ritmo Cassinese), 363 (Rainaldo e Lesengrino). The expression also occurs in the dicerie, the political eloquence, but regularly connected to a noun: "Signori cittadini«, "Signori consiglieri«, "Signori delle arti« (Honourable citizens, Honourable counsellors, Honourable members of the corporations). Cf. Pregnolato, Dicerie negli autografi. I thank Professor Enrico Artifoni for his kind suggestions. 
or else a concluding sentence was gleaned from it:

Nunquam dominus temporalis faceret tales uindictas quales facit Dominus Noster. Vnde le vendete de Dio son molto forti et stranie (No lord of this world would know how to exact vendettas as those of Our Lord. Indeed the vengeance of God is very strong and unpredictable) (47r)

[Petrus] oblitus erat societatem suorum sociorum quos dimiserat ad pedem montis, vnde non uidebatur curare de eis. Vnde pare che sanctu Petru pocu se curasse de loro $k a$ avesse bene ipse (Peter had forgotten about his companions whom he had left at the foot of the mountain [Tabor], and thus it seemed as though he had not thought of them. It thus seems that Saint Peter took little care of them, provided that he was well) (101v);

or the consequences of an action are expressed more concretely:

Sed ue illis qui de prelio redeuntes incidunt inter gladios et spatas et lanceas et tutti sonno tagliati (But woe be to those who returning from battle end up among the daggers and the swords and the spears of the enemies and are all cut to pieces) (302r)

[Mercator] multis periculis se exponit quia uadit per contratam dubiam et aliquando inter ascaranos qui robant et occidunt eos et chosì vaniscu della persona et dell'avere. (The merchant exposes himself to many dangers because he goes to dangerous countries and at times amid bandits who steal from and kill the merchants, and so are stripped of their life and their possessions/wealth) (303v).

\section{Conclusion}

Vernacular words only exceptionally appear in thirteenth-century Latin sermons. Angelo da Porta Sole's preaching, as well as the sermons of contemporary friars not yet adequately studied (for instance the Franciscan Bindo Schelmi), suggests an increasing mixture of Latin and Italian during the first half of the fourteenth century. Isolated vernacular words (technical terms as well as proverbial phrases) contribute to a clear and lively communication, which is a crucial element for an effective sermon. In the sermons of Friar Angelo the use of this form of "organic " change between the two linguistic codes is more frequent than in the former preachers. Moreover, a sudden and repeated switching of the languages is the most remarkable characteristic of his style, something that clearly enhanced his oral performance. Although at times curious and "inorganic", the language switching aims to ensure effective communication of the religious message. Therefore, its use is reserved for particular moments in the sermons in order to impress these on the memory of the audience. The vernacular language frequently served to highlight the multiple forms of direct speech: the fictional dialogue between the preacher and his public (sermocinatio), the dialogue between the characters in the exemplary tales, or the ironic and satirical comments of the preacher. Vernacular dialogues and utterances often underline the most dramatic presentation of the Gospels, particularly of the Passion; in this case, Angelo da Porta Sole was probably also influenced by the contemporary dramatic religious poetry (the laudi drammatiche), inspired by the Dominicans in Perugia and diffused in the confraternities of the town. A remarkable feature is also his frequent use of the apostrophe Signori, which was a characteristic allocution in the jester literature. The sermon collection of Angelo da Porta Sole shows that already at the beginning of the fourteenth century macaronic hybridism was an important communication tool for addressing the laity. This text, therefore, allows us to trace in its infancy a phenomenon that reached a fully developed form almost two centuries later. Between the late fifteenth century 
and the early sixteenth century, particularly in the Veneto region, some famous and popular preachers, such as Bernardino da Feltre and Valeriano da Soncino, developed these forms of linguistical switching in an extraordinary way and created a new, original macaronic style, almost a particular language of preaching. The aim of the sermon was still the instruction of the audience and the reform of customs, yet they inclined its language to literary and ludic performance, even imitating the macaronic poetry. While these developments were still to come at the time of Angelo da Porta Sole, the linguistic awareness and the search for an effective way to address the audience with vernacular expressions were already part of the work of the most skilful preachers. 


\title{
References
}

\author{
Abbreviations \\ CCCM = Corpus Christianorum Continuatio Mediaevalis \\ CISAM = Fondazione Centro italiano di studi sull'alto medioevo \\ GDLI = Grande Dizionario della Lingua Italiana (Turin, 1961-2002)
}

\section{Manuscripts}

Città del Vaticano, Biblioteca Apostolica Vaticana, MS Barb. Lat 3932 (Lettere spirituali).

Firenze, Biblioteca Nazionale Centrale, Conv. Soppr. B.8.1637.

Siena, Biblioteca Comunale, MS T IV 7.

\section{Edited Sources}

Acta Capitulorum Provincialium Provinciae Romanae (1243-1344), ed. Thomas Kaeppeli and Antonius Dondaine (Rome, 1941).

Ageno, Franca, La lingua della cronaca todina di Ioan Fabrizio degli Atti, Studi di filologia italiana 13 (1955) 167-227.

Agostini, Francesco, Il volgare perugino negli »Statuti del 1342«, Studi di filologia italiana 26 (1968) 91-199.

Antologia della poesia italiana: Duecento, ed. Cesare Segre and Carlo Ossola (Torino, 1977).

Sancti Antonii Patavini, Sermones dominicales et festivi, ed. Beniamino Costa, Leonardo Frasson, Giovanni Luisetto and Paolo Marangon (Padua, 1979).

Avalle D'Arco, Silvio, La parodia della »Lex Salica«, in: Silvio Avalle D’Arco (ed.), Protostoria delle lingue romanze (Turin, 1965) 377-378.

Baldelli, Ignazio, Glosse in volgare cassinese del secolo XIII, in: Ignazio Baldelli (ed.), Medioevo volgare da Montecassino all'Umbria (Bari, 1971) 5-92.

Baldelli, Ignazio, La lauda e i disciplinati, in: Ignazio Baldelli (ed.), Medioevo volgare da Montecassino all'Umbria (Bari, 1971) 323-364.

Baldelli, Ignazio, L'uso del volgare nel ducato di Spoleto, in: Ignazio Baldelli (ed.), Conti, glosse e riscritture dal secolo 11 al secolo 20 (Naples, 1988) 91-108.

Bériou, Nicole, Latin and the vernacular: Some remarks about sermons delivered on Good Friday during the thirteenth century, in: Volker Mertens and Hans-Jochen Schiewer (eds.), Die deutsche Predigt im Mittelalter (Tübingen, 1992) 268-284.

Bériou, Nicole, Latin et langues vernaculaires dans les traces de la parole vive des prédicateurs, in: Stéphanie Le Briz and Géraldine Veysseyre (eds.), Approches du bilinguisme latin-français du Moyen Age: Linguistique, codicologie, esthétique (Turnhout, 2010) 191-206.

Bériou, Nicole, Religion et communication: Un autre regard sur la prédication au Moyen Âge (Geneva, 2018).

Bernardino da Siena, Prediche volgari sul Campo di Siena (1427), ed. Carlo Delcorno (Milan, 1989).

Billanovich, Giuseppe, La tradizione del testo di Livio e le origini dell'Umanesimo 1: Tradizione e fortuna di Livio tra Medioevo e Umanesimo (Padua, 1881).

Bourgain, Pascale, Analyse linguistique et stylistique des sermons de Saint Antoine, in: Congresso internacional Pensamento e testemunho: $8^{\circ}$ Centenario do nascimento de santo Antonio, Actas 1 (Braga, 1996) 125-146. 
Buridant, Claude, Les binômes synonymiques: Esquisse d'une histoire des couples de synonymes du Moyen Âge au XVIIe siècle, Bulletin du Centre d'analyse du discours 4 (1980) 5-79.

Catanelli, Luigi, Raccolta di voci perugine, introd. Francesco A. Ugolini (second revised and expanded edition) (Perugia, 1970).

La Cronaca di S. Domenico di Perugia, ed. Andrea Maiarelli, CISAM 126/78 (Spoleto, 1995).

Dante, Alighieri, Purgatorio: A verse translation by Jean Hollander and Robert Hollander (New York, 2003).

Delcorno, Carlo, »Antico« e "moderno« nel sermone medievale, in: Giovanni Baffetti, Giorgio Forni, Silvia Serventi, Oriana Visani (eds.), "Quasi quidam cantus": Studi sulla predicazione medievale (Florence, 2009) 105-121.

Delcorno, Carlo, Giordano da Pisa (Giordano da Rivalto), in: Istituto dell'Enciclopedia Italiana (ed.), Dizionario biografico degli italiani 55 (Rome, 2000) 243-251.

Delcorno, Carlo, The language of preachers: Between Latin and vernacular, The Italianist 15 (1995) 48-66.

Delcorno, Carlo, La lingua dei predicatori: Tra latino e volgare, in: Giovanni Baffetti, Giorgio Forni, Silvia Serventi, Oriana Visani (eds.), "Quasi quidam cantus": Studi sulla predicazione medievale (Florence, 2009) 21-46.

Dessì, Rosa Maria, Porta Sole, Angelo da, in: Istituto dell'Enciclopedia Italiana (ed.), Dizionario biografico degli italiani 85 (Rome, 2016) 110-112.

Dessì, Rosa Maria, Les spectres du Bon Gouvernement d'Ambrogio Lorenzetti: Artistes, cités communales et seigneurs angevins au Trecento (Paris, 2017) 113-121.

Giovanni Dominici, Lettere spirituali, ed. Maria Teresa Casella and Giovanni Pozzi (Freiburg, 1969).

Guillelmi Alverni, Sermones de Tempore, ed. Franco Morenzoni, CCCM 230 (Turnhout, 2010). Iacopo da Varazze, Sermones quadragesimales, ed. Giovanni Paolo Maggioni (Florence, 2005). Iacopone da Todi, Laudi, trattato e detti, ed. Franca Ageno (Spoleto, 2015).

Iacopone da Todi, Laude, ed. Francesco Mancini (Bari, 1974).

Johnson, Holly, The Grammar of Good Friday: Macaronic Sermons in Late Medieval England, SERMO 8 (Turnhout, 2012).

Kaeppeli, Thomas, Inventari di libri di San Domenico di Perugia (1430-1480), Sussidi Eruditi 15 (Rome, 1962).

Kaeppeli, Thomas, Scriptores Ordinis Praedicatorum Medii Aevi 1, Monumenta Ordinis Fratrum Praedicatorum Historica (Rome, 1970).

Lausberg, Heinrich, Elementi di retorica (Bologna, 1969).

Lazzerini, Lucia, »Per latinos grossos...«: Studio sui sermoni mescidati, Studi di filologia italiana 29 (1971) 219-339.

Lazzerini, Lucia, Il testo trasgressivo: Testi marginali, provocatorî, irregolari dal Medioevo al Cinquecento (Milan, 1988).

Mancini, Francesco, Vocabolario del dialetto todino, Studi di filologia italiana 18 (1960) 319377.

Mattesini, Enzo, Dialetti moderni e antichi volgari in Umbria: Il caso del folignate. Appunti linguistici su tre statuti di corporazioni artigiane (secc. XIV-XV), in: Luciano Agostiniani, Margherita Castelli and Domenico Santamaria (eds.), L'Umbria nel quadro linguistico dell'Italia mediana (Gubbio, 18-19 giugno 1988) (Perugia, 1990) 163-204.

Paoli, Ugo Enrico, Il latino maccheronico (Florence, 1959). 
Pellegrini, Letizia, I manoscritti dei predicatori, Institutum Historicum Fratrum Praedicatorum: Dissertationes Historicae 26 (Rome, 1999).

Poeti del Duecento, ed. Gianfranco Contini (Milan, 1960).

Polo de Beaulieu, Marie Anne (ed.), Formes dialoguées dans la littérature exemplaire du Moyen Âge (Paris, 1989).

Pregnolato, Simone, Le Dicerie negli autografi del Ceffi, Studi di filologia italiana 76 (2018) 5-90.

Reinhard, Toni, Umbrische Studien, Zeitschrift für romanische Philologie 72 (1956) 48-52.

Segre, Cesare, La tradizione macaronica da Folengo a Gadda (e oltre), in: Opera critica (Milan, 2014) 838-855.

Sella, Pietro, Glossario latino emiliano, Studi e Testi 74 (Vatican, 1937).

Sella, Pietro, Glossario latino-italiano: Stato della Chiesa, Veneto, Abruzzi, Studi e Testi 109 (Vatican, 1944).

Smalley, Beryl, English Friars and Antiquity in the Early Fourteenth Century (Oxford, 1960).

Soulier, Pellegrino Maria, Inventarium codicum manuscriptorum monasterii SS: Annuntiatae de Florentia, in: Monumenta Ordinis Servorum S. Mariae, Société Belge de Libraire 4 (Brussels, 1903-1904).

Testi trecenteschi di Città di Castello e del contado, ed. Francesco Agostini, Scrittori italiani e testi antichi publicati dall'Accademia della Crusca (Florence, 1978).

Trabalza, Ciro, Saggio di vocabolario umbro-italiano e viceversa (Bologna, 1982).

Ugolini, Francesco A., Annali e Cronaca di Perugia in volgare dal 1191 al 1336 (Perugia); taken from the Annali della Facoltà di Lettere e Filosofia della Università degli studi di Perugia 1 (1963-1964).

Wenzel, Siegfried, French proverbs from the mouths of English preachers, in: Siegfried Wenzel, Of Sins and Sermons (Leuven, 2015) 227-238.

Wenzel, Siegfried, Macaronic Sermons: Bilingualism and Preaching in Late Medieval England (Ann Arbor, 1994). 